\title{
The Nursing Graduate Program at 40 Years: What Can We Commemorate?
}

\author{
Rosa Maria Godoy Serpa da Fonseca ${ }^{1}$, Margareth Ângelo², Elizabeth Fujimori ${ }^{3}$, \\ Maria Luiza Gonzalez Riesco ${ }^{4}$
}

According to Cortella(1), the word "commemorate" almost always refers to "having a party"; however, commemorating means remembering with others or, in other words, remembering together, which does not imply a festive remembrance. However, in our society, especially in daily use, the word "commemorate" is usually employed with its primary meaning: celebrating with a party ${ }^{(2)}$.

In this editorial, when we refer to the $40^{\text {th }}$ anniversary of the Nursing Graduate Program (Programa de Pós-Graduação em Enfermagem-PPGE), we will do so with this double meaning. Furthermore: according to the plea of the carnival song written by Aldacir Marins and Macedo (1955), in these brief words we will remember and live through unique moments of one of the oldest - and most history-filled - graduate programs in all of Brazilian nursing.

The Nursing Graduate Program was created in 1973 "to address the legal demands for educational qualification for higher learning, when there was a political need to meet such demands and facilitate access to higher education in the most populous urban centers. The Graduate Program was created precisely to meet the demands for academic development of those who were already involved in higher education or had the intention to do so"(3). It never deviated from its original motto, carrying out the mission to: 1) Qualify nurses and other healthcare professionals to make contributions to the production of knowledge and scientific updates, with the objective of fostering the advancement of innovative knowledge; 2) Generate changes in care and management practices in nursing and health care, bringing together the knowledge of nursing science and other areas.

In that sense, in the last four decades, many creative measures have been taken to confront the challenges and difficulties in the process of implementation and development. One of those challenges has been trying to overcome the chronic contradiction between existing resources - especially human - and the necessities linked to the performance of educational and research activities. We know that any growth implies increasing commitments towards searching for more distant horizons, but as a rule, there are usually not enough resources for such a task.

The last reorganization of the Nursing Graduate Program in 2010 established its current structure, based on a core titled "Theoretical and methodological foundations that support nursing and health care" and two guiding axes: "Public policies for health and human resources in nursing and health care" and "The health-disease process in individuals, families, social groups and the collectivity." The axes, which circle the described core, interface with the area of concentration: Care in Health.

The focus has been the development of professionals capable of advancing research and leading actions with the objective of producing knowledge that is consistent and socially relevant for the current challenges of local and global heath. Up to July 2014, we had presented 1,106 degrees, of which 868 were for Master's programs and 238 for Doctoral programs; $42 \%$ of those degrees were completed in the last decade. The qualification of professionals who are committed to the development of advanced health care practices, within the legal and ethical scope of the profession, can be attested to by the participation of our alumni in educational institutions, management of health care services and relevant positions that define the implementation of public policies that meet the demands of society.

Since its inception, and in agreement with its current objectives, the Program has kept its commitment to the development of human resources aimed at universities in Brazil and overseas. Therefore, it has also historically been responsible for the qualification of faculty who are active in coordination of important nursing graduate programs all across the country, management positions at educational institutions and leadership of research groups.

In addition, the current appeal of universities worldwide for internationalization has driven us to increase our visibility beyond the borders of South America, where we have been present since the early days. Highlights in this area are the initiatives to approach European and North American institutions, with the objective of sharing experiences and knowledge through exchange programs for faculty and students. At this moment in history, it is a matter of survival to carry out educational and investigative efforts to overcome the challenge of making Brazilian nursing part of the global structure of committed and ethical knowledge, for the benefit of human development. It is not enough just to produce knowledge, it must be relevant - usefula and usableb - to enable social transformation. Simply producing and handing

\footnotetext{
${ }^{1}$ Full Professor, Department of Collective Health Nursing, School of Nursing of the University of São Paulo. Member of the Coordination Board of the Nursing Graduate Program - 2014-2016 Administration, São Paulo, São Paulo, Brazil. ${ }^{2}$ Full Professor, Department of Collective Health Nursing, School of Nursing of the University of São Paulo. Coordinator of the Nursing Graduate Program - 2011-2013 Administration, São Paulo, São Paulo, Brazil. ${ }^{3}$ Associate Professor, Department of Collective Health Nursing, School of Nursing of the University of São Paulo. Coordinator of the Nursing Graduate Program - 2014-2016 Administration, São Paulo, São Paulo, Brazil. ${ }^{4}$ Associate Professor, Department of Mother-Child and Psychiatric Nursing, School of Nursing of the University of São Paulo. Vice-Coordinator of the Nursing Graduate Program - 2014-2016 Administration, São Paulo, São Paulo, Brazil.
} 
out diplomas is not enough, it is crucial that those holding the degrees perform their social role beyond what they wrote in dissertations, theses and articles.

In this special edition of the Journal of School of Nursing at the University of São Paulo, we bring to the public a small sample of our most recent work. We believe that in carrying out these efforts, faculty and students contribute to fostering reflection and transforming health care and nursing practice that is increasingly focused on the effective improvement of the quality of life of each citizen, family and group in our society. From that point of view, we believe we have reason to commemorate. However, considering that knowledge is a collective product that can only be meaningful if used collectively, we propose a final thought for our readers: Do we really have something to commemorate?

\section{Referências}

1. Cortella MS. Não espere pelo Epitáfio: provocações filosóficas. Petrópolis: Vozes; 2005.

2. Houaiss. Grande dicionário eletrônico HouaissBeta da língua portuguesa [Internet]. Rio de Janeiro: Objetiva; 2009 [citado 2014 jul. 20]. Disponível em: http://houaiss.uol.com.br/busca?palavra=comemorar

3. Oguisso T, Tsunechiro MA. História da Pós-Graduação na Escola de Enfermagem da Universidade de São Paulo. Rev Esc Enferm USP [Internet]. 2005 [citado 2014 jul. 20];39(n.esp):522-34. Disponível em: http:// www.scielo.br/pdf/reeusp/v39nspe/v39nspea04.pdf

4. Que conceito: seu novo conceito em dicionário [Internet]. [citado 2014 jul. 20]. Disponível em: http:// queconceito.com.br/utilidade\#ixzz38nhNGIdx

\footnotetext{
a The concept of usefulness refers to "the quality of that which is useful. Usefulness is what you can get from some object or situation. Things may have some use or not. But that does not depend on the object, but on who has a use for the object. Use is what makes something useful, that gives the used object a certain value to fulfill the needs of the human being"(4) b Usable refers to the concept of usability - which may be defined as the study or the use of techniques or instruments (knowledge) that enable the facilitation of use of a given object. Usability has the objective of ensuring that an individual can use a given instrument (knowledge) and that it works as it should. It is a concept derived from computer science, but has been discussed and used regarding knowledge [Personal communication of Doctorate Professor Maria do Céu Roldão, School of Education of the Catholic University of Santarém, Lisbon, Portugal]
} 